\title{
DONOSY NA JÓZEFA MACKIEWICZA
}

\author{
Wacław LEWANDOWSKI (Toruń)
}

Sprawie oskarżeń Józefa Mackiewicza o rzekomą niegodną przeszłość okupacyjną i kolaborację z okupantami poświęcono już bardzo wiele uwagi, by wspomnieć tylko najważniejszą na ten temat pracę - Ptasznika z Wilna Włodzimierza Boleckiego. Każdy, kto się z tą historią zapoznawał, miał okazję stwierdzić nadzwyczajną zaciekłość oskarżycieli, rodzącą podejrzenie, że tłem nagonki były zadawnione polityczne i personalne spory rodem $\mathrm{z}$ ciasnego przecież, międzywojennego wileńskiego podwórka. Z czasem, już na emigracji, do zwalczających pisarza wilnian dołączali nie-wilnianie, coraz to nowi polityczni przeciwnicy, pragnący zamknąć usta niewygodnemu autorowi, którego najchętniej wykluczyliby z polskiej społeczności i skazali na społeczny niebyt. Uwadze badaczy ,sprawy Mackiewicza” umknął jednak jeden ważny zespół archiwalny — zbiór dokumentów Armii Krajowej i Delegatury Rządu RP w Wilnie, znajdujący się w wileńskim Litewskim Centralnym Archiwum Państwowym (Lietuvos Centrinis Valstybès Archyvas), zmikrofilmowany i skatalogowany jako FR-601, AP 1. Zbiór ten przechował się pod posadzką kościoła franciszkanów w Wilnie i został stamtąd wydobyty już w czasach litewskiej niepodległości. Jak dotąd, korzystał zeń jeden tylko polski autor, wileński badacz dziejów prasy polskiej na Litwie, Józef Szostakowski ${ }^{1}$. Pośród wielu innych dokumentów tego archiwalnego korpusu znajdują się także meldunki dotyczące osoby Józefa Mackiewicza, mające charakter donosów pisanych z wyraźną intencją zaszkodzenia pisarzowi i przedstawiających go w jak najgorszym świetle.

1 Zob.: J. Szostakowski, Między wolnościq a zniewoleniem. Prasa w języku polskim na Litwie w okresie od września 1939 do 1964 roku, Wilno-Warszawa 2004. 
Dostarczane przez samorzutnych ,informatorów” nie były lekceważone, lecz trafiały w ręce najstarszych rangą osobistości wileńskiego podziemia, później zaś do Delegatury Rządu RP w Warszawie, gdzie - wolno przypuszczać - uznawane były za wiarygodne informacje z regionu, potwierdzone u źródła. Donosów musiało być więcej niż się zachowało, skoro na liście osób podejrzanych o uchybianie obowiązkom patriotycznym (FR-601, AP 1, B 81, L 16) na pozycji 372a figuruje: Mackiewicz Józef zam. Czarny Bór z komentarzem: ,podał się za Lit[wina], w czasie okup[acji] niem[ieckiej] za Volksdeutscha”. Jest oczywistym, że tego rodzaju listę układano na podstawie napływających ,z terenu” informacji...

Spośród zachowanych meldunków najważniejszym wydaje się sporządzony przez niejakiego „W. Porębskiego”, nazwanego ,przygodnym informatorem”, który trafił m.in. do rąk „Ludwika” - Lubosława Krzeszowskiego (1897-1965), wówczas podpułkownika, szefa sztabu i zastępcy komendanta Okręgu Wileńskiego AK oraz do „Albina” - Zygmunta Federowicza (1889-1973), Delegata Rządu na Okręg Wileński, który sporządził meldunek „,pro memoria”, uzupełniając informacje „Porębskiego”. Dokumenty przygotowano do druku unikając większych zmian. Zmodernizowano pisownię, pozostawiono jednak interpunkcję oryginałów. W przypadku maszynopisów znaki ,//" zastapiono nawiasem - „, ( )". Pozostawiono różniące autorów osobliwości pisowni — np. w zapisie nazwisk: „Łebkowski” — „Łepkowski”; „Hrynkiewiczówna” — „Grynkiewiczówna”. Nie poprawiono oczywistych „spolszczeń” w zapisach nazwisk litewskich. Nie ingerowano w składnię. Ograniczono komentarz, by nie powtarzać (poza niezbędnymi) informacji podawanych w literaturze na temat „sprawy Mackiewicza".

\section{Notatka „Alfreda” do „Ludwika” (FR-601, AP 1, B 51, L 1)}

4 IV - 1944 r.

Sz. Panie,

Przesyłam do ew. wykorzystania meldunek poświęcony organizacji personalnej niemieckiej propagandy [słowo wykreślone] prasowej w Wilnie. Powyższy meldunek w pewnym stopniu może stanowić materiał dla rzeczowego i poważniejszego opracowania tego zagadnienia. Wobec tego, iż w zawartych charakterystykach osób jest sporo nieścisłości dołączam notatkę prostującą niektóre fakty i opinie.

Alfred

\section{Meldunek „Porębskiego” (FR-601, AP 1, B 51, L 2-4) ${ }^{\text {** }}$}

Propaganda

Założyciel i pierwszy kierownik był Kopferman. Urzędował do grudnia 1942 r. następnie wyjechał do Kowna.

Skład obecny:

\footnotetext{
* Notatka odręczna.

*** Maszynopis, 3 karty.
} 
Werner Klau — szef propagandy (Berlińczyk były naucz[yciel]) gimn[azjum] w Berlinie. Witold Alsejka - szef gospodarczy zastępca Klawego (Wychowanek uniwersytetu Stefana Batorego były dziennikarz „Elity” — Litwin).

Cenzura:

Klau, tłumacz na litewski Alsejka, tłumacz na polski Jacobi (cenzor) i Zarańska (Jacobi syn naucz. gimn. wileńskiego, obecnie narodow. niemiec. Zarańska Polka).

Obsługa informacyjna:

Alsejka, Danowska (maszynistka — siła fachowa) Hohenlindgerówna (tłumaczenie na polski).

„Wilnaer Zeitung":

Redagowany i wychodzi w Kownie. Wydawca — „Pressevertzieb” (spółka niem.) Redaktor nacz. Kakies (zniemczały Litwin kłajpedzianin). W Wilnie jeden przedstawiciel redaktora, drukuje się jedna strona.

„Goniec Codzienny”:

Feliks Lubierzyński - redaktor naczelny (Polak były redaktor „Przeglądu Artystycznego”, poza tym autor broszurek i artykulików „,nierealnych” o okultyzmie, spirytyzmie, seksualizmie, siła woli, itp. Człowiek bez żadnego wyrazu politycznego).

„Administracja”:

Administracja prawie całkowicie pokrywa się z byłą administracją „Słowa” [Stefan] Wiszniewski — dyrektor administracji (Polak, można nazwać patriota, człowiek z charakterem, antykomunista). Helena Hrynkiewiczówna buchalterka-kasjerka (Polka, prowadzi dział ofiar. Nie ma specjalnie mocnych przekonań politycznych — choćby antykomunistyczne. Jako człowiek z racji prowadzenia pomocy dla biednych, zasługuje na całkowite uznanie). Władysław Łebkowski redaktor techniczny (jeden z najlepszych fachowców w Wilnie jako „łamacz [w oryg.: Tamacz] gazety”, Polak, prawdopodobnie o nastawieniu patriotycznym znalazł się w „Gońcu” przypadkowo tak jak zresztą i wszyscy inni dzięki swemu nastawieniu antykomunistycznemu). Ławrynowicz - reporter (bez wyrazu, zdradzając[y] pewne tendencje do robienia kariery, to znaczy obecnie cały[m] sercem pragnie powrotu Polski i normalnych stosunków ale gdyby stało się inaczej prawdopodobnie ze spokojem i zapałem pracowałby na rzecz okupanta. Oczywiście mogłoby być inaczej, ale takie są moje wrażenia). Bohdan Mackiewicz, dział ogłoszeń, Mikołaj Baranowski - prenumerata: obaj są przeciętni urzędnicy. Poza tym: dwóch tłumaczy, 3 maszynistki, kancelistki (m. innymi Irena Piłsudska córka Jana).

„Naujoji Lietuva”:

W „Naujoji Lietuva” trzech ludzi jest „,ważniejszych” reszta to plejada „mniejszych" urzędników o zgodnych poglądach antypolskich, antysowieckich i antyniemieckich [w oryg.: natyniemieckich].

Tyszkus — redaktor naczelny

Szaltenis - zastępca red., redaktor literacki

Narkeliunate Salomea — dział informacji lokalnych

„Biełaruski Hołas”:

Franciszek Alechnauski — redaktor naczelny [dop. ręką: „! Olechnowicz”]

Paulukouski Michał? - pozostałe funkcje administracyjne.

Poza tym „Biełaruski Komitet” którego członkowie rozsiani po całej Wileńszczyźnie pisujący różne ,artykuły” w tym i antypolskie.

Historia „Gońca Codziennego” [w oryg. całość w cudzysł.]:

Kilka dni po objęciu przez władze partyjne administracji na terenie Litwy, zgłosił się do ówczesnego szefa propagandy Kopfermana pan Józef Mackiewicz, z propozycją 
założenia polskiego pisma. Ponieważ pan Kopferman był zdania, że może być mowa tylko o piśmie niemieckim, w języku polskim, powstała między wyżej wymienionymi różnica zdań, wskutek czego Mackiewicz został wyrzucony (dosłownie) z gabinetu (i ze schodów). Nie dając za wygran[a], Mackiewicz proponuje innym dziennikarzom utworzenie pisma niemieckiego (w języku polskim). Podjął się tej misji Czesław Ancerewicz. Nakład „Gońca” osiągnął zawrotną jak na stosunki wileńskie cyfrę 80.000 egzemplarzy. Były mniejsze nakłady, wskutek braku papieru (najwyższy 35.000 egzemplarzy). Ponieważ wszyscy pracownicy, mieli wyznaczoną pensję (dość niską zresztą) cała nadwyżka z kolportażu, szła na konto propagandy przy generalkomisariacie, oddział Wilno. Po dwóch miesiącach urosła wcale poważna sumka 60.000 marek. Jak Kopferman ją zużytkował o tym potem. Teraz sylwetki założycieli „Gońca”:

Kopferman, idealny typ germana-hitlerowca, uważający każdego kto nie Niemiec, za bydło, parobka który bez szemrania i wymagań musi służyć niemieckiemu panu. W czasie swego urzędowania w Wilnie, traktował swoich podwładnych (Niemców) w najbardziej brutalny i bezwzględny sposób. Jako przykład może posłużyć fakt, że w niczym nie ułatwił swojemu personelowi zdobycie [przydziału] na należne im ordery, żywności lub drzewa. On uważał każdy środek za dobry, jeżeli chodziło o propagandę antypolską. Jemu zawdzięcza „Biełaruski Hołas” swoje „narodziny”. Jemu zawdzięcza „Naujoji Lietuva” tak liczne zmiany swoich redaktorów. On, spławił tak wiernego germanofila, jakim był Rafał Mackiewicz. On, pisał artykuły wstępne do „Gońca”, jak i do innych gazet miejscowych, występując w imieniu Polaków, Litwinów, czy też Białorusinów. Z zawodu nauczyciel wiejski, o wychowaniu i syntementalności [sentymentalności; mentalności?] chłopa. Obecnie dygnitarz partyjny, wierny i nieprzekupny. Przyjechał do Wilna z gołymi rękami, wywiózł wyjeżdżając [,,nieprzekupny” i „wywiózł wyjeżdżając” podkreślone piórem, na lewym marginesie karty zaznaczone znakiem ,?’, najpewniej przez przyjmującego meldunek] cztery samochody różnych cennych rzeczy, jak ubrania, meble stylowe itp., prawdopodobnie żydowskie. Józef Mackiewicz. Dziennikarz bez politycznej równowagi. W innych okolicznościach byłby bardzo dobrym dziennikarzem od sensacji. W warunkach wojennych fatalnie zachybotał się. Bez wattpienia Polak i patriota, wywołał niejednokrotnie oburzenie społeczeństwa wileńskiego. Na koncie dorobku dziennikarskiego ma: „oda na cześć Litwinów” w „Lietuvos Żynos [prawidłowo: Žinios]” [19]39 r. ${ }^{2}$, Kowno, ataki na „Kurier Wileński” w „Gazecie Codziennej” (słuszne czy niesłuszne, jednakże niewłaściwe wobec sytuacji politycznej wówczas, natomiast pogłoski jakoby „Gazeta Codzienna" była finansowana przez Litwinów nie odpowiadają prawdzie, owszem Litwini początkowo sądzili, że "Gazeta” będzie organem prolitewskim, po pewnym zawiedzeniu się wydali „Nowe Słowo” pod redakcją Sakowicza, sprowadziło to fale konfiskat na „Gazetę”. Wracając do „konta” Mackiewicza można zanotować artykuł „Będziemy pisać prawdę” po zajęciu Litwy przez sowietów (pisany — przypuszczam bez przekonania) ${ }^{3}$. Następuje okres odsunięcia się od publicystyki (do czasu przyjścia Niemców pracował jako „domowy woźnica”). Inicjator założenia „Gońca Codziennego", starał się o to (jak sam twierdzi) w celu pokazania Niemcom przewagi ludności polskiej w Wilnie, im [i?], żeby móc się wypowiedzieć wobec zaszłych sensacyjnych

\footnotetext{
${ }^{2}$ Chodzi o artykuł My, wilnianie..., ogłoszony w przekładzie litewskim (Mes vilniečiai...) w nrze 234 „Lietuvos Žinios” z 14 października 1939. Zob.: J. Mackiewicz, Nudis verbis, Londyn 2003, s. 205-208.

${ }^{3}$ Artykuł pt. Będziemy mówili prawdę opublikował J. Mackiewicz w 1. nrze „Gazety Codziennej”, 25 listopada 1939 r., po opuszczeniu Wilna przez wojska sowieckie i przejęciu miasta we władanie przez Litwinów (28 października 1939 r.). Zob.: Nudis verbis, s. 209-211.
} 
zmian politycznych. I znana jego wyprawa do Katynia. Po założeniu „Gońca” umieścił tam prawie całą administracjęe „Słowa”. Można jeszcze zanotować napisaną przed niedawnym czasem nowelę, utrzymaną w tonie satyryczno-humorystycznym, z czasów okupacji litewskiej w Wilnie w której to wyszydza (słusznie) ówczesnego przedstawiciela rządu Czeczota. [na lewym marginesie piórem odnotowano: ?!] Tytuł: „U konfesjonału" . Napisana na maszynie przechodzi z rąk do rąk i jest czytana przez społeczeństwo wileńskie. Inne osoby odegrały zdaje się mniejszą rolę przy założeniu „Gońca”.

„Naujoji L[i]etuva”:

Natychmiast po wkroczeniu Niemców do Wilna zgłosił się do władz wojskowych niejaki Wilniantas, który otrzymał koncesję na wydanie pisma w języku litewskim (,Naujoji L[i]etuva"). Redaktorem tego pisma został znany ultr[a]-germanofil Rafał Mackeviczius. Ów założyciel Wilniantas wraz z żoną Jegomościanką (nazwisko) pochodził z Tylż[y] i wraz z całą rodziną Wilmantasów i Jegomościów (którzy mieli dużą i wielce zasłużoną drukarnię w Tylży) zostali wymienieni na Niemców z Litwy (dobrowolnie) za czasów okupacji sowieckiej, podczas ogólnej wymiany ludności. Po objęciu władzy przez administrację partyjna, Wilmantasy i Jegomoście znikli, zostało po nich tylko opieczętowane mieszkanie. Zostali rozstrzelani lub wywiezieni gdzieś daleko do obozu. Należy dodać, że byli to ludzie bardzo kulturalni, wszyscy z wyższym wykształceniem.

Rafał Mackiewicz, zagorzały germanofil, osobisty przeciwnik Józefa Mackiewicza, a zwłaszcza jego żony Toporskiej, skompromitował się w oczach Niemców przez zbytnią gorliwość, a mianowicie przedrukowując ze „Schwarze Korps” artykuł pt. „Organizacj[a] ziem wschodnich po wojnie" (miał z tego powodu dużą burzę, ówczesny cenzor a obecny szef Klau, który od tego czasu stał [się s]urowszy i pilnie przegląda wszystko, co ma być napisane). Mackiewicz zaś (Rafał) został po kilku mniejszych „kiksach” przez swoich panów po prostu zlikwidowany. Redaktorów ogólnie w „Naujoji L[i]etuva" było czterech, a mianowicie: Mackiewicz Rafał, Żukauskas, Mackiewicz (po raz drugi), Żukas, Tyszkus. Żukas, wychowanek USB, charakter mocny i prawy, lubiący Niemcom mówić prawdę w oczy, został po dwóch tygodniach redaktorowania przez Niemców zlikwidowany.

„Naujoji L[i]etuva” cieszy się w odróżnieniu od „Gońca”, który dostaje wszystko gotowe, względną swobodą. Redaktorzy piszą artykuły wstępne, reporterzy artykuły o sprawach kulturalnych i lokalnych. Kurs polityczny jest znany.

„Biełaruski Hołas”:

„Biełaruski Hołas”, „dziecko” Kopfermana, powstał z nadwyżki finansowej „Gońca”. Owe pierwsze 60.000 RM przyczyniły się do założenia i zasilenia kasy białoruskiej szmaty (która sama nie jest wystarczalna). Tak to „genialne” posunięcie Kopfermana, za polskie pieniądze, rozpętało antypolską propagandę. Artykuły nawołujące do mordowania księży i prześladowania ludności polskiej odniosły skutek, przeważnie w powiatach lidzkim, nowogródzkim, baranowickim.

Były mordy na ludności polskiej, a w Baranowiczach zakazano używania mowy polskiej pod karą grzywny. Sylwetki ,redaktorów” są bardzo podłe, i zresztą Alechnowicz

\footnotetext{
${ }^{4}$ Książkę tę napisał J. Mackiewicz w 1942 r. Jej maszynopis (w dwóch egzemplarzach) puścił w obieg podziemny. Ocalały egzemplarz znajduje się w Bibliotece Litewskiej Akademii Nauk w Wilnie (sygn. F12-2695). Był on podstawą wydania książkowego, zob.: J. Mackiewicz, Prawda w oczy nie kole, Londyn 2002. W informacji od edytora czytamy: „Tytuł Przy konfesjonale napisany na osobnym arkuszu, w mojej opinii, nie ręką Mackiewicza, został prawdopodobnie nadany przez kogoś pod wrażeniem zdania «Piszę tu raczej spowiedź osobistą na tle wypadków, tak jak mi przychodzą na pamięć i na myśl, wypadków jeszcze się rozgrywających i nie zakończonych» (s. 129)"; [N. Karsov], Od wydawcy, [w:] J. Mackiewicz, Prawda w oczy..., s. [6].
} 
już nie żyje, a Paulukouski, jeżeli dociągnie końca wojny, to stanie przed sądem polskim. Warto zaznaczyć jeszcze, że Białorusinom polskim nie wolno używać alfabetu rosyjskiego, zaś Biał[orusinom] sowieckim — łacińskiego. Jeżeli już mowa o Białorusinach, to trzeba wspomnieć jeszcze o bardzo pięknie brzmiącym nazwisku Henryk Odlanicki-Poczobut[t] $]^{5}$, zam. w Wilnie, ul. św. Ignacego 3-2 (dom dość. św. Katarzyny [prawdopodobnie: „dościenny”, tj. styczny ścianą z budynkiem klasztoru benedyktynek. Na zaułek św. Ignacego prowadziło tylne wyjście klasztoru i kościoła św. Katarzyny — W. L.]). Jest to literat, który nic nie napisał. Wydał przed wojną kilka numerów miesięcznika „Niemen”. Naukowe sfery litewskie uważają go wręcz za szpiega niemieckiego.

[Na rewersie karty opisy piórem:]

/-/ W. Porębski

[W poprzek karty:] Archiwum opinie pracowników

[U dołu:] Pająki L. 265/P Mp. [miejsce postoju] 19 III 44

Ludwik [podkreślone, zapewne wskazanie adresata] Meldunek przygodnego informatora przesyłam do ewentualnego wykorzystania [podpis:] Krzywak

[Niżej:] Bip [BIP?] Przesyłam do wykorzystania 31 III 44 [podpis:] L

[Niżej:] Lisy L 346/2[?]/44 Mp. dn. 27. 5. 44

[Niżej:] Ludwik Przedstawiam Nowosielski

\section{Uzupełnienia „Alfreda” (FR-601, AP 1, B 51, L 6-8) *}

Ad. cenzura. Hohendlingerówna — znana w Wilnie jako „Ciocia Hala” — współpracowniczka Radia Polskiego.

Ad. „Goniec Codz” Feliks Lubierzyński, b. redaktor „Przeglądu Artystycznego” — formalny Polak, pod względem moralnym osobistość pozbawiona skrupułów, grafoman. „Przegląd Art.” był wydawnictwem opierającym swój budżet na pewnego rodzaju szantażach autorów i artystów, zwłaszcza młodych, początkujących, którym zależało na reklamie. Poza tym pozycją dochodową były ogłoszenia uzyskiwane w niezbyt solidny sposób. Zbieraniem ogłoszeń trudnił się sam Lubierzyński, który był jednocześnie redaktorem, administratorem, akwizytorem wydawnictwa ukazującego się nieregularnie w zależności od połowu na rynku ogłoszeniowym i artystyczno-autorskim. Rola F. L. w Gońcu sprowadza się do markowania stanowiska redaktora, ponieważ wszystko co w Gońcu jest drukowane poza kroniką przesyłane jest przez W. Klau’a.

Władysław Łepkowski, redaktor techniczny, Polak, trafił do Gońca zaagitowany przez Józefa Mackiewicza z którym pracował w „Słowie” i „Gazecie Codziennej”. Pozbawiony pionu patriotycznego i mocniejszych poza antykomunistycznymi, przekonań politycznych. Dobry „łamacz gazety”, reporter od wypadków policyjnych, swoją karierę dziennikarską rozpoczął w „Expressie Wileńskim”, poprzednio zaś pracował jako agent policji politycznej w latach 1922-[192]4.

\footnotetext{
${ }^{5}$ Najprawdopodobniej chodzi o Stanisława Poczobutt-Odlanickiego, ekonomistę rolnictwa, asystenta USB, członka, wraz z Franciszkiem Olechnowiczem, Białoruskiego Komitetu Narodowego, prowadzącego w Wilnie (od lutego do kwietnia 1944 r.) rozmowy z podziemiem polskim pod patronatem Komendy Głównej AK. Zob.: L. Tomaszewski, Wileńszczyzna lat wojny i okupacji 1939-1945, Warszawa 2001, s. 320.

* Rękopis, 3 strony, 2 zapisane obustronnie, w lewym górnym rogu 1. karty skośnie, z podkreśleniem: pro memor. (pro memoria).
} 
Administracja „G. Codz.” tylko częściowo składa się z b. pracowników administracji „Słowa” (2 osoby). Po wyjeździe do Warszawy [Eugeniusza] Kotlarewskiego administracja „G[ońca] Cod[ziennego]” znajduje się w rękach dwóch osób: Stefana Wiszniewskiego i Bohdana Mackiewicza. Stefan Wiszniewski b. pracownik Inst. Europy Wschodniej, oficer rezerwy Polak - głównym motywem który skłonił go do pracy w Gońcu Codz były względy materialne i obawa przed pracą fizyczną.

Bohdan Mackiewicz, Polak, b. kierownik filii „Kuriera Warszawskiego” w Wilnie, osobistość pod względem patriotyczno-moralnym raczej negatywna, b. wrażliwy na względy materialne, typ drobnego biznesmena niezbyt przebierającego w metodach handlowych.

Helena Grynkiewiczówna - buchalterka-kasjerka, jedyna spośród pracowników przedwojennych wydawnictw polskich w Wilnie, która potrafiła za[a]klimatyzować się początkowo w „Prawdzie Wileńskiej” a później w „Gońcu Codz”. Ta zdolność przystosowywania się świadczy o dużym życiowym sprycie. Polka raczej formalna z dużym nalotem rusyfikacyjnym, wiele lat bowiem spędziła w Rosji, gdzie wyszła za mąż za Rosjanina z którym się rozwiodła i wróciła do Wilna po I wojnie światowej w r. 1922. Pracowała początkowo w księgarni Stow. Nauczycielstwa Polsk[iego], następnie w wydawn[ictwie] „Słowa”. Wyraźnych przekonań politycznych nie posiada.

Mikołaj Baranowski, b. ekspedytor „Słowa”, prawosławny, spolonizowany Rosjanin, zdecydowany antykomunista, dobry pracownik techniczny.

Ad. ,historia Gońca Cod[ziennego]” [podkreślone]

Do Kopfermana zgłaszał się w sprawie założenia pisma polskiego Józef Mackiewicz i Wacław Studnicki. Zgłoszenie ułatwił kuzyn Józefa Mackiewicza Jerzy Matułajtis, Litwin, obecny opiekun teatrzyku „Ali Baba” (w kołach litewskich J. Matułajtis posiada b. złą opinię jako ciemny aferzysta). Po pierwszej przykrej rozmowie z Kopfermanem w Propaganda Staffel — Baltikum Józef Mackiewicz zrezygnował z zamiaru ubiegania się o pismo na własne imię, wysunął natomiast kandydaturę Ancerewicza, który podjął się „redagowania” Gońca w myśl życzeń niemieckich. Za ,pomysł i inicjatywę" otrzymał Józef Mackiewicz pewien \% dochodów pochodzących z kolportażu pisma. Do czasu wypadku z Ancerewiczem ${ }^{6}$ sumy wypłacane z tego tytułu przez głównego kolportera Pawłowskiego były dzielone pomiędzy Ancerewicza, Kotlarewskiego (administratora) i Mackiewicza.

Ad. „Gazeta Codzienna” [podkreślone] Pogłoska o tym jakoby „Gazeta Codzienna” założona wspólnie przez adwokata Bolesława Szyszkowskiego i Józefa Mackiewicza była finansowana przez Litwinów powstała stąd, że w momencie gdy się "Gazeta” miała ukazać środkiem płatniczym obowiązującym w Wilnie był lit. Na zlecenie delegata rządu kowieńskiego Bizauskasa oddział Banku Litewskiego otworzył redakcji „Gazety Codz[iennej]” kredyt w wysokości 2 tys. litów w celu ułatwienia wybrnięcia z trudności płatniczych. Kredyt ten został spłacony.

Ad. „U konfesjonału” [podkreślone] Pełny tytuł napisanej na maszynie broszury J. Mackiewicza brzmi „U konfesjonału Europy Wschodniej”. Składa się ona z kilku artykułów-reportaży drukowanych w „Gazecie Codziennej” oraz dość nieudolnej próby wytłumaczenia i obrony wolt polityczno-publicystycznych w pamiętnych dniach września i października 1939 r. które tak oburzyły społeczeństwo wileńskie.

Ad. „Naujoji Lietuva” [podkreślone] — Rafał Mackiewicz b. sekretarz Komitetu Litewskiego w Wilnie i prawa ręka Staszysa [długoletniego prezesa Wileńskiego Komi-

\footnotetext{
${ }^{6}$ Na mocy wyroku polskiego Sądu Specjalnego Czesław Ancerewicz został zastrzelony 16 marca 1943 r. w kościele św. Katarzyny w Wilnie.
} 
tetu Litewskiego, w 1939 r. po wkroczeniu Litwinów do Wilna mianowanego burmistrzem - W. L.] zmienił, po okupowaniu Wilna przez Litwinów w r. 1939 swe nazwisko na Rafał Mackonis. Do września 1939 Mackiewicz-Mackonis przedstawiał się jako liberalnie-pojednawczo nastawiony Litwin, po zajęciu Wilna przez Smetonę zdemaskował się jako zoologiczny szowinista i wróg zacięty Polaków.

\section{Meldunek anonimowy (FR-601, AP 1, B 51, L 5)*}

Józef Mackiewicz z Jawnutą-Zawiszą (dziennikarzem i znanym warchołem z Litwy figura moralnie b. marna) wyjeżdżają do Szwecji ${ }^{7}$. Otrzymał od Niemców dużo złota i z jaką́s misją polityczną jest przez nich wysyłany. Wyjeżdża dziś czy jutro. Ma rzekomo zrobić ,,jakąś sztukę polityczną”. - O tej sprawie może poinformować panna Bobkówna z biura prasowego niemieckiego — o działalności Wł. Studnickiego ${ }^{8}$ może dużo powiedzieć ks. Kretowicz ${ }^{9}$.

Jak widać z powyższego, ,panna Bobkówna”, o której nic mi nie wiadomo, zapewne osoba szlachetna i „wtyczka” AK w niemieckim biurze, gdyby okoliczności ułożyły się inaczej, mogłaby być gwarantem życia lub śmierci wybitnego pisarza...

\footnotetext{
${ }^{*}$ Notatka odręczna, niepodpisana.

7 Józef Mackiewicz wspominał: ,[W Warszawie] przyszedł do mnie Konrad Krupski z wydziału wschodniego podziemnej Delegatury i oświadczył, że krążą plotki, że w Wilnie zapadł na mnie ‘jakiś' wyrok [...]. Jednocześnie pokazał mi tajny meldunek pochodzący z Wilna, że ja wysłany zostałem przez gestapo do... Sztokholmu! [...] Było to w lipcu 1944 roku." Cyt. za: K. Zamorski, Przylepiło się do Józefa Mackiewicza, Puls 1987 nr 34, s. 63.

${ }^{8}$ Pomyłka, mowa nie o Władysławie, ale o Wacławie Gizbert-Studnickim, przed wojną dyrektorze archiwum wileńskiego.

${ }^{9}$ Ks. Jan Kretowicz był proboszczem kościoła bernardynów.
} 